
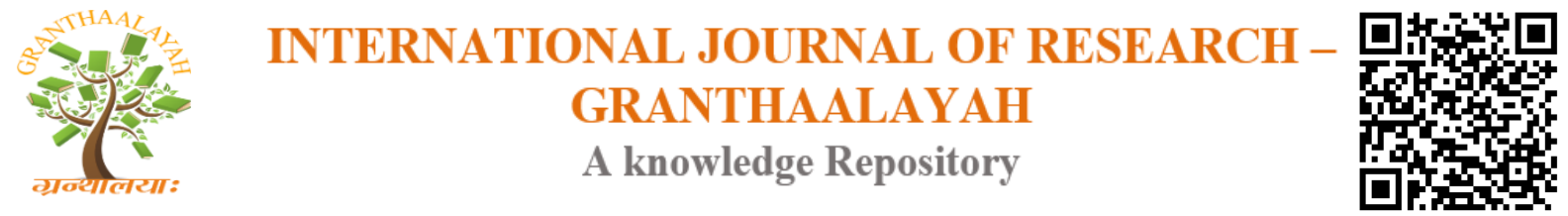

Science

\title{
DEVELOPING A UNIFIED FACIAL TISSUE THICKNESS MODEL FROM NEUROIMAGING DATA FOR SRI LANKA USING STATISTICAL ANALYSIS AND IMAGE PROCESSING TECHNIQUES
}

\author{
Lochana T. Batuwitage ${ }^{* 1}$, Aparni Jayawardena ${ }^{2}$, Himashi Sandamini ${ }^{3}$, Roshan N. \\ Rajapakse $^{4}$, Damitha D. Karunaratna ${ }^{5}$, Muditha Vidanapathirana ${ }^{6}$, Aruna Pallewatte ${ }^{7}$ \\ $* 1,2,3,4,5$ University of Colombo School of Computing, Colombo, Sri Lanka \\ ${ }^{6}$ Department of Forensic Medicine, Faculty of Medical Sciences, University of Sri
}

Jayewardenepura, Sri Lanka

${ }^{7}$ National Hospital of Sri Lanka

Funded by University of Sri Jayawardenapura, Sri Lanka

\begin{abstract}
Facial soft tissue thickness (FSTT) is essential to forensic anthropologists for facial reconstruction- recreating a recognizable face from an unidentified skull and to plastic surgeons for treatment planning. Together with the age and sex of a person, the facial profile is related to facial soft tissue thickness, which is required for accurate facial reconstruction and recognition. Having such a facial profile in the national level is very important for a country since FSTT changes according to the geographical factors.

In this paper we are presenting a review on literature associated with this topic describing the methods used for data collection, measuring FSTT and analyzing those values along with the method we are proposing to be followed in the research we are to conduct in the Sri Lankan context.
\end{abstract}

Keywords: Facial Reconstruction; Ultrasound; CT; MRI; ANOVA; SPSS.

Cite This Article: Lochana T. Batuwitage, Aparni Jayawardena, Himashi Sandamini, Roshan N. Rajapakse, Damitha D. Karunaratna, Muditha Vidanapathirana, Aruna Pallewatte. (2017). "DEVELOPING A UNIFIED FACIAL TISSUE THICKNESS MODEL FROM NEUROIMAGING DATA FOR SRI LANKA USING STATISTICAL ANALYSIS AND IMAGE PROCESSING TECHNIQUES." International Journal of Research - Granthaalayah, 5(7), 354-362. https://doi.org/10.29121/granthaalayah.v5.i7.2017.2141.

\section{Introduction}

In the field of forensic science, one frequently has to deal with unidentified skeletonized remains, where the challenge is to identify the "unidentifiable". At such an instance, Forensic facial reconstruction (FFR) is the process by which facial approximations are generated by using the skeletal remains of the deceased. Facial soft tissue thicknesses (FSTT) hold an important role in 
FFR. So prevalence of adequate data on facial soft tissue thickness (FSTT) for facial reconstruction would make it possible to reconstruct the face which looks much similar to the deceased person. In addition to the FFR, during accidents, this comes into action. Sometimes the face of the people gets injured badly and they have to be undergone with plastic surgeries to take the face back to normal. Before reconstructing or altering the face through a plastic surgery, it is necessary to determine the shape of the face. For that it is important to know the FSTT at particular defined landmarks.

According to the literature when considering about the global context, developed countries possess unified Soft Tissue Thickness models for their own contexts. When we come to the Sri Lankan context, currently there is no repository in national level which contains tissue thickness values for all the age groups in Sri Lanka. Through the early stages of this research, the researchers have attempted to analyze skin tissue thickness patterns pertaining to the Sri Lankan population of the 20-30 age category [1]. When considering the above instances, it would be a great advantage to have a database with facial tissue thickness related to the Sri Lankan context, which can be used as a reference to get FSTT values. Many local medical officers also highlighted the national importance of a comprehensive set of data covering all age groups for Sri Lanka.

\section{Sample Selection}

The facial soft tissues are those from the skin surface to the most superficial surface of the underlying bone. The facial soft tissues consist of three layers as skin, subcutaneous tissue (mainly of fatty tissue) and muscle [2]. According to the literature, facial soft tissue thickness in different facial areas varies with the gender [3] and the age. Therefore, in this research subjects will be to classified considering their gender and age ranges (As male and female considering the gender and the age ranges as 20-30,31-40,41-50,51-60 and 60 and above).

Table 01 gives some more details of studies conducted in the past with the age range and sample size which they selected.

The age range and sample size for this research were selected by analyzing similar studies conducted by other countries in the past. Table 02 represents the number of samples that are planned to be collected for this project.

Table 1: Age range and sample size of some past studies

\begin{tabular}{llll}
\hline $\begin{array}{l}\text { Study name } \\
\text { Age range }\end{array}$ & Selected age groups & $\begin{array}{l}\text { Sample size per } \\
\text { each range }\end{array}$ \\
$\begin{array}{l}\text { Facial soft tissue thickness } \\
\text { database for craniofacial } \\
\text { reconstruction in the Turkish }\end{array}$ & $18-90$ years & $18-29,30-39,40-49$, & 32 (Male - 16, \\
adult population & & $50-59$ and over 60 years & female - 16) \\
Bulut, O. et al. 2014 [4] & & \\
\hline
\end{tabular}


Facial soft tissue thicknesses of the mid-face for Slovak population

Panenkova, P. et al. 2012 [5]

Midline facial soft tissue thickness database of Turkish population: MRI study Sipahioglu, S. et al. 2011 [6]

Facial soft tissue thickness database of Gujarati population for forensic craniofacial reconstruction Lodha, A. et al. 2016 [7]

$$
18 \text { - } 87 \text { years 18-39. 40- } 59 \text { and over }
$$

60

$18-78$ years

18- $34,35-45,46-55$

Around 38

and over 56 years

Table 2: Tissue thickness sample size calculation

\section{Category description}

The age range in consideration for the project

Genders

Tissue thickness samples per category

Complete number of Samples

\section{Elements included in the category}

20- 60 years and 60 years and above 5
Number included for each element

Male \& Female

2

16

$16 \times 2 \times 5=160$

\section{Data Collecting Techniques}

\subsection{Needle Depth Probing Method}

In 1883 Hermann Welcker used this method (the initial data collecting method) according to the first documented research on FTT measurements [8]. Most recently in 2005 a study was held on Australian Caucasoid decedents using this method. Limitations of this method are, this method can only be used on cadavers and dehydration problems associated with cadavers which may lead to error prone results. In the later years, following the development of modern technology, more recent and advanced methods were employed in taking soft tissue depth measurements.

\subsection{Ultrasound Technique}

Ultrasound has been found useful and has been the method of choice for many modern researchers on soft tissue measurement as it is simple and inexpensive, requires no radiation exposure, and can be performed with the patient seated. 
Wing Nam Joyce Chan used ultrasonic measurements to conduct study to find the Facial tissue depths of Chinese-Americans in New York City [11]. In this research ultrasound measurements were taken at 19 landmarks across the faces of 101 individuals aged from 18 to 87 years. Limitation they have identified in using ultrasound is that the deformation of the soft tissues with the pressure applied by placing the fat transducer equipment.

In 1996, Aulsebrook has stated some drawbacks of the ultrasound technique in his research, "Facial soft-tissue thicknesses in the adult male Zulu", Subjective errors may occur in the angulation of the ultrasonic probe with bone, since the angle to the bone at which the measurement is taken alters the value of the measurement, and holding the probe perpendicular to the skin surface does not necessarily mean that the depth will be measured perpendicular to the bone [9].

\subsection{Computerized Tomography (CT)}

CT scanning is a technique that uses a computer to reconstruct a 3D image of the internals of an object from a large series of 2D radiographic images (axial and coronal slices). It has been particularly useful in anthropometric studies since it provides good definitions of both the skull and face images (Tilotta et al. 2009) [12]. High image contrast is seen between the bone (appearing white due to higher radio density) and subcutaneous soft tissues or musculature (appearing grey to dark), as well as the soft tissue versus air. One can clearly detect the margins of the bone and skin (Shimofusa et al. 2009)[9], therefore making it possible to take an accurate measurement from a specific landmark on the bone to the surface of the skin.

In the research study, Facial Soft Tissue Thicknesses Prediction Using Anthropometric Distances by Quang Huy Dinh et al,,a database was obtained using CT techniques. The researchers have adapted this technique as it is fast, accurate, can produce high quality images and produces high visualization of the bone. [13]

Since the CT scanners cannot be carried out here and there, the subjects should be directed to where the scanner is. Due to the radiation exposure, the sample should be selected through a voluntary process. To limit this in most of the studies the samples are selected from the patients who obtain CT scans for medical purposes.

Literature indicates that Cone Beam CT (CBCT) as a novel, reliable technology and alternative to $\mathrm{CT}$ technique. It offers better high spatial resolution, diminished ionizing radiation, and rapid data acquisition $[14,15]$ compared to the CT technique. Moreover, It allows patients to be in a sitting position thus, reducing measurement distortion due to soft tissue displacement caused by the force of gravity [16]. With this advantage this technique has been used to measure the facial tissue thickness of Colombian adults [17] where CBCT images of 30 living, adult subjects from both sexes (26 males and four females) between 18 and 35 years of age were used for the study. Yet, CBCT has the disadvantage of exposing the subjects to radiation as CT technique which can limit access to a considerable sample size [17]. 


\subsection{Magnetic Resonance Imaging (MRI)}

With an added advantage of Excellency in the visualization of soft tissue over other methods, today the Magnetic Resonance Imaging (MRI) technique is used for collecting data.

In 2011 a study was conducted to create a reference database of facial tissue thickness in the Turkish population by Serdar Sipahioglu a, Hakan Ulubay b, H. Barıs, Diren. The study included 161 patients ( 79 males and 82 females) between the ages of 18 and 78 who had undergone brain MRI. Measurements were taken at 9 points at the midline. Another aim of this study was to present data illustrating the successful use of MRI for this purpose. An odd number of sections were chosen from all the patients and the researchers have ensured that the middle section was the true midsagittal section. T1-weighted (TR: $500 \mathrm{~ms}$, TE: $15 \mathrm{~ms}$, NE: 1) sagittal section measurements were used for the study. The T1-weighted sequence was preferred as it shows fat tissue and anatomical details more clearly [6].

Unlike in CT scanning in MRI, the subjects and the researchers are not exposed to the radiation. However than all mentioned techniques MRI scanning is somewhat expensive. Due to that reason the number of studies conducted using this method is very low.

\section{Data Measuring Techniques}

Once the data is collected should measure the FSTT of each sample. Under the needle depth probing method, the FSTT is measured through the depth which the needle goes into the cadaver's body. However, this technique is low reliable when compared to others, because of the postmortem changes occur in the cadavers and it affects the accuracy of the data a lot. In 1980 Rhine and Campbell offset some possible deformations created during this technique by using hands to level the skin. Also to eliminate the effect from the postmortem changes, people who deceased for less than 12 hours or cadavers only been refrigerated overnight were selected. In 2001 Evision found that in addition to the postmortem changes which occur, the positioning of a cadaver too affects the results [18]. In 2005, De Greef et al noticed a significant difference in the results of cadavers in the upright position versus the supine [10]. So can conclude even this method is useful in a situation where live samples and new technological equipment's cannot be accessed, the reliability and the accuracy of this method is highly challengeable.

The advantage of using ultrasound technique over other techniques is the ability to measure the facial tissue thickness from the internal calipers of the ultrasound system. In 2011, Chan et al used this method for their study [11]. Through the internal calipers of the Aloka SSD-500 OB/GYN ultrasound system the distance between the bone and the skin of Chinese American adults in the New York City was measured in this research. Moreover, ultrasound technique seems to be one of the accurate and safe as it can be used without any considerable threat for the candidate according to literature.

Besides, ultrasound technique the major advantage of using high-resolution imaging methods such as CT and MRI is that they allow the capture and modification of cross- sectional images of complex anatomical structures and thus enable 3D soft-tissue measurement. By constructing 
either a 2D or a 3D model and locating the landmarks on the skull surface of the sample the tissue thickness can be measured.

In the early stages of this research tissue thickness from CT images of 60 Sri Lankan adults (30 men and 30 women) ranging age from 20-30 years was measured using Osirix Lite software [1]. Another study was done in Korea in order to establish a facial soft tissue thickness database for craniofacial Reconstruction in Korean adults. For the study data was collected using the CBCT (cone beam volume CT) scans. Maxillofacial 3D images were created from the DICOM data acquired from the CBCT scans using V Works 4.0 (CyberMed, Seoul, Korea). A couple of 3D object files were constructed with an adjustment of Hounsfield Unit (HU): one for hard tissue image with 550-650 HU and another for a CT image with 570 to $500 \mathrm{HU}$. Both soft and hard tissue images were imported into specific software, Skull Measure (CyberMed), to measure the distance between a point on the ST image and corresponding point on the hard tissue image.

In 2013, a study was done to determine facial soft tissue thickness of Colombian adults; FSTT was measured using images acquired via CBCT [19]. The acquired CT DICOM images were exported to iCATVision software (Imaging Sciences International, Hatfield, PA, USA) to locate and measure facial thicknesses. It was possible to locate 17 landmarks of the 21 standard based on Rhine et al. [17]. The midline points were located in a sagittal view and the bilateral points in an axial view. Facial soft tissue thickness measurements were made by following the methodology described by Cavanagh and Steyn [20] by tracing a line tangential to the bone surface and then a perpendicular line to that and extended outward to meet the facial profile.

In the MRI study done to create a reference database in the Turkish population, the measurements were performed using a picture archiving and communication system (PACS) computer workstation. Measurements were taken at 9 points along the midline.

In our research we will be using both CT and MRI images for purpose of measuring facial tissue thickness of the Sri Lankans. The results gained from both image acquiring types will be considered separately and compared with each other. So that a more accurate final result can be gained for the research.

\section{Data Analysing Techniques}

The gathered data should be analyzed to see the usefulness of it. When referring to the literature, both statistical and computational analysis methods can be identified.

Below mentioned are the analysis methods used in the literature. 
Table 3: Analysis methods used in the literature

\begin{tabular}{|c|c|c|c|c|c|}
\hline Study & $\begin{array}{l}\text { FTT and } \\
\text { gender }\end{array}$ & $\begin{array}{l}\text { FTT and } \\
\text { age }\end{array}$ & $\begin{array}{l}\text { FTT and } \\
\text { BMI }\end{array}$ & $\begin{array}{l}\text { Level of } \\
\text { significanc } \\
\text { e }\end{array}$ & $\begin{array}{l}\text { Statistical } \\
\text { package } \\
\text { used for } \\
\text { the } \\
\text { analysis }\end{array}$ \\
\hline $\begin{array}{l}\text { In Vivo Facial Tissue } \\
\text { Depth Study Of } \\
\text { Chinese-Americans In } \\
\text { New York City Win } \\
\text { Nam Joyce et al } 2007 \\
{[11]}\end{array}$ & $\begin{array}{l}\text { Student's T } \\
\text { test }\end{array}$ & $\begin{array}{l}\text { Pearson's } \\
\text { correlation } \\
\text { and } \\
\text { ANOVA } \\
\text { techniques }\end{array}$ & $\begin{array}{l}\text { Pearson's } \\
\text { correlations } \\
\text { and the } \\
\text { ANOVA }\end{array}$ & $\begin{array}{l}\mathrm{p}<0.05 \\
\text { (for all } \\
\text { statistical } \\
\text { analyses) }\end{array}$ & \\
\hline $\begin{array}{l}\text { In-vivo facial depth } \\
\text { measurements for } \\
\text { children and adults } \\
\text { Manhein M. H et al } \\
2000 \text { [21] }\end{array}$ & $\begin{array}{l}\text { Pearson's } \\
\text { correlation, } \\
\text { analysis of } \\
\text { variance, } \\
\text { and paired } \\
\text { t-tests }\end{array}$ & $\begin{array}{l}\text { Pearson's } \\
\text { correlation, } \\
\text { analysis of } \\
\text { variance, } \\
\text { and paired } \\
\text { t-tests }\end{array}$ & & & \\
\hline $\begin{array}{l}\text { Midline facial soft tissue } \\
\text { thickness database of } \\
\text { Turkish population: } \\
\text { MRI study Sipahioglu S. } \\
\text { et al } 2011 \text { [6] }\end{array}$ & $\begin{array}{l}\text { one way } \\
\text { ANOVA } \\
\text { and } \\
\text { independen } \\
\mathrm{t} \text { T test }\end{array}$ & $\begin{array}{l}\text { one way } \\
\text { ANOVA } \\
\text { and } \\
\text { independen } \\
\mathrm{t} \text { T test }\end{array}$ & $\begin{array}{l}\text { one way } \\
\text { ANOVA } \\
\text { and } \\
\text { independen } \\
\mathrm{t} \text { T test }\end{array}$ & $\begin{array}{l}\mathrm{p}<0.05 \text { (for } \\
\text { all } \\
\text { statistical } \\
\text { analyses) }\end{array}$ & $\begin{array}{l}\text { SPSS, } \\
\text { version } 14\end{array}$ \\
\hline $\begin{array}{l}\text { Facial soft tissue } \\
\text { thickness database of } \\
\text { Gujarati population for } \\
\text { forensic craniofacial } \\
\text { reconstruction } \\
\text { Lodha A. et al [7] }\end{array}$ & $\begin{array}{l}\text { Discrimina } \\
\text { nt function } \\
\text { analysis } \\
\text { and t-test }\end{array}$ & & & $\mathrm{p}<0.05$ & $\begin{array}{l}\text { SPSS } \\
\text { version } \\
20.0\end{array}$ \\
\hline $\begin{array}{l}\text { Facial soft tissue } \\
\text { thickness of Colombian } \\
\text { adults [17] }\end{array}$ & $\begin{array}{l}\text { Mann- } \\
\text { Whitney U } \\
\text { test }\end{array}$ & & ANOVA & $\begin{array}{l}\mathrm{P}<0.05 \text { (for } \\
\text { all } \\
\text { statistical } \\
\text { analyses) }\end{array}$ & $\begin{array}{l}\text { SPSS, } \\
\text { version } \\
13.0, \text { IL, } \\
\text { USA }\end{array}$ \\
\hline Use of Neural Networks & & & & & \\
\hline $\begin{array}{l}\text { Facial Soft Tissue } \\
\text { Thicknesses Prediction } \\
\text { Using Anthropometric } \\
\text { Distances } \\
\text { Dinh Q. } 2011 \text { [13] }\end{array}$ & \multicolumn{2}{|c|}{$\begin{array}{l}\text { Relationship between } \\
\text { the anthropometric } \\
\text { distance and the } \\
\text { thickness at each } \\
\text { anthropometric } \\
\text { landmark }\end{array}$} & \multicolumn{3}{|c|}{$\begin{array}{l}\text { Linear regression and Artificial Neural } \\
\text { Networks (Multi-Layer Perceptron) has } \\
\text { used for data processing }\end{array}$} \\
\hline
\end{tabular}


In most of the instances ANOVA and t-test are used for the analysis purposes.

However, in order to adapt a neural network based analysis it may require a large number of sample data as training and testing sets are separately needed to be determined. Therefore, most of the research studies have used statistical based approach and have gone for neural based approach in order to validate the statistical analysis approach.

In our research we are hoping to use the statistical approach for the analysis purpose and upon the availability of the data we will go for a neural network method for the analysis.

\section{Conclusion}

Facial soft tissue thickness is an important factor which determines the facial reconstruction of individuals. Out of the methods used for collecting FSTT, though needle depth probing method was used at past, Ultrasound, CT, Cone Beam CT and MRI are widely used techniques at present. Each method has its advantages over disadvantages. By studying the literature we can conclude that MRI is the best technique to distinguish soft tissues and tissue detail in different planes, making it superior to other imaging techniques.

Statistical analysis methods like ANOVA, Pearson's correlation and Student's T test techniques, linear regression method are widely used for the data analysis purposes. Out of the studies in literature, majority has taken SPSS software for the statistical analysis purposes.

Few studies have used machine learning techniques to the data processing in FSTT analysis. Those studies have proved that, as the neural network has the ability to find patterns and irregularities, as well as detecting multi-dimensional nonlinear connections in data, applying neural networks to predict the soft tissue thicknesses for facial reconstruction will produce better output over other techniques. Evaluations of the results have been done through Leave- one-out approach and Ten- fold cross validation. From these two techniques Leave- one-out approach has been the technique used widely.

When considering the Sri Lankan context still only a single pilot study has been carried out associating the topic forensic facial reconstruction. So we planned to give our collaboration towards this field through a research on developing a unified facial tissue thickness model from neuroimaging data for Sri Lanka using statistical analysis and Image processing techniques to fill the gap within Sri Lanka. Here we will be using MRI and CT scan images for data gathering and statistical techniques for data analysis. Finally we will deliver a facial soft tissue thickness database and a unified tissue thickness model for the Sri Lankan context to be used for all the reconstruction purposes.

\section{References}

[1] Anuradha K. Madugalla, Roshan N. Rajapakse, Ishari U. Amarasinghe, Vinavi H. Padmathilake, Anuja T. Dharmaratne, Damitha Sandaruwan. "FaceID: A 3D computer graphic application for forensic medicine: A novel semi-automated muscle based digital sculpting initiative for forensic facial reconstruction in Sri Lanka", Computer Medical Applications (ICCMA), International Conference, 2013 
[2] M. Xu and J. Yang, "Human Facial Soft Tissue Thickness and Mechanical Properties: A Literature Review", Volume 1A: 35th Computers and Information in Engineering Conference, 2015.

[3] K. Cha, "Soft-tissue thickness of South Korean adults with normal facial profiles", The Korean Journal of Orthodontics, vol. 43, no. 4, p. 178, 2013.

[4] O. Bulut, S. Sipahioglu and B. Hekimoglu, "Facial soft tissue thickness database for craniofacial reconstruction in the Turkish adult population", Forensic Science International, vol. 242, pp. 4461, 2014.

[5] Petra Panenková, Radoslav Beňuš, Soňa Masnicová, Zuzana Obertová , Ján Grunt. "Facial soft tissue thicknesses of the mid-face for Slovak population". Forensic Science International, Volume 220, Issues 1-3, Pages 293.e1-293.e6, 10 July 2012.

[6] Serdar Sipahiog lu, Hakan Ulubay, H. Barıs Diren. "Midline facial soft tissue thickness database of Turkish population: MRI study". Forensic Science International journal, 2012 Jun 10;219(1-3).

[7] Anand Lodha, Mitalee Mehta, M.N. Patel, Shobhana K. Menon. "Facial soft tissue thickness database of Gujarati population for forensic craniofacial reconstruction"

[8] M. Manhein, G. Listi, R. Barsley, R. Musselman, N. Barrow and D. Ubelaker, "In Vivo Facial Tissue Depth Measurements for Children and Adults", Journal of Forensic Sciences, vol. 45, no. 1, p. 14640J, 2000.

[9] Aulsebrook WA1, Becker PJ, Işcan MY. "Facial soft-tissue thicknesses in the adult male Zulu" Forensic Science International journal, 1996 May 31.

[10] De Greef S, Claes P, Mollemans W, Loubele M, Vandermeulen D, Suetens P, Willems G. "Semiautomated ultrasound facial soft tissue depth registration: method and validation",Journal of Forensic Sciences,50(6):1282-8, 2005 Nov.

[11] Wing Nam Joyce Chan. 'IN VIVO FACIAL TISSUE DEPTH STUDY OF CHINESEAMERICANS IN NEW YORK CITY.', May 2007, pp.23.

[12] F. Tilotta, F. Richard, J. Glaunès, M. Berar, S. Gey, S. Verdeille, Y. Rozenholc and J. Gaudy, "Construction and analysis of a head CT-scan database for craniofacial reconstruction", Forensic Science International, vol. 191, no. 1-3, pp. 112.e1-112.e12, 2009.

[13] Q. Dinh, T. Ma, T. Bui, T. Nguyen and D. Nguyen, "Facial Soft Tissue Thicknesses Prediction Using Anthropometric Distances", New Challenges for Intelligent Information and Database Systems, pp. 117-126, 2011.

[14] W.C. Scarfe, A.G. Farman, "What is cone beam CT and how does it work? Dent. Clin. N. Am. 52 (2008) 707-730.

[15] F.A. Quereshy, T.A. Savell, J.M. Palomo, "Applications of cone beam computed tomography in the practice of oral and maxillofacial surgery”, J. Oral. Maxillofac. Surg. 66 (2008) 791-796.

[16] Hyeon-Shik Hwang, Myoung-Kyu Park, Won-Joon Lee, Jin-Hyoung Cho, Byung-Kuk Kim, Caroline M. Wilkinson. "Facial Soft Tissue Thickness Database for Craniofacial Reconstruction in Korean Adults", Journal of Forensic Sciences, Vol. 57, No. 6, November 2012

[17] N. Perlaza Ruiz, "Facial soft tissue thickness of Colombian adults", Forensic Science International, vol. 229, no. 1-3, pp. 160.e1-160.e9, 2013.

[18] Martin P. Evison, "Modeling Age, Obesity, and Ethnicity in a Computerized 3-D Facial Reconstruction”, Forensic Science Communications, Volume 3 - Number 2, April 2001.

[19] Z. Fourie, J. Damstra, P.O. Gerrits, Y. Ren. "Accuracy and reliability of facial soft tissue depth measurements using cone beam computer tomography", Forensic Sci. Int. 199 (2010) 9-14

[20] D. Cavanagh and M. Steyn, "Facial reconstruction: Soft tissue thickness values for South African black females", Forensic Science International, vol. 206, no. 1-3, pp. 215.e1-215.e7, 2011.

[21] Welcker, H.: Schiller's schadel und todenmaske, nebst mittheilungen uber schadel und todenmaske kants. (1883)

*Corresponding author.

E-mail address: 1thathsaranee@ gmail.com 